\title{
Pengaruh Glukosa Tinggi terhadap Proliferasi, Migrasi dan Ekspresi Gen OCT-4 pada Kultur Sel Dermal Fibroblast Manusia
}

\section{The Effects of High Glucose on Proliferation, Migration and Expression of OCT-4 in} Human Dermal Fibroblast Cell Culture

\author{
Restu Syamsul Hadi ${ }^{1}$, Yurika Sandra ${ }^{2}$ \\ ${ }^{1}$ Department of Biology-Anatomy, Faculty of Medicine, YARSI University, Jakarta \\ ${ }^{2}$ Department of Biochemistry, Faculty of Medicine, YARSI University, Jakarta \\ Jalan Letjen. Suprapto, Cempaka Putih, Jakarta 10510 \\ Telephone (021) 4206674, 4206675, 4206676 \\ Corresponden: restuhadi@gmail.com
}

\begin{abstract}
Abstrak
Human dermal fibroblasts (HDF) termasuk sel mesenchymal yang diisolasi dari lapisan dermis kulit. HDF berpotensi digunakan untuk pengobatan penyembuhan luka berdasarkan pengobatan regeneratif. Peningkatan konsentrasi glukosa dapat merusak fungsi sel dan menghambat terapi penyembuhan luka. Penelitian ini dilakukan untuk mengkaji pengaruh glukosa tinggi pada proliferasi, migrasi dan ekspresi gen OCT-4 sel HDF sebagai model penyembuhan luka diabetes in vitro. Pada penelitian eksperimental ini, fibroblast diisolasi dari kulit setelah sirkumsisi, kemudian ditumbuhkan dalam medium Minimal Essential Medium (DMEM) Dulbecco lengkap dengan serum 10\%. Untuk menguji efek glukosa tinggi pada proliferasi sel HDF dilakukan dengan uji CCK-8. Migrasi sel HDF dievaluasi menggunakan uji scratch-assay. RT-PCR digunakan untuk menentukan ekspresi gen OCT4. Hasilnya menunjukkan bahwa glukosa tinggi (25 mM-50 mM) meningkatkan kemampuan proliferasi dan migrasi sel HDF. Efek glukosa tinggi tergantung pada dosis. Perlakuan glukosa pada dosis 75 $\mathrm{mM}$ akan menghambat kemampuan pertumbuhan HDF. Ekspresi gen OCT-4 meningkat secara bermakna pada pemberian glukosa dosis $25-50 \mathrm{mM}$. Hasil penelitian ini memberikan dasar untuk pengembangan terapi dalam kondisi diabetes bahwa terapi sel HDF dapat meningkatkan penyembuhan luka meskipun dalam kondisi glukosa tinggi.
\end{abstract}

Kata kunci: fibroblast kulit manusia; glukosa tinggi; proliferasi; migrasi; ekspresi gen OCT

\section{Abstract}

Human dermal fibroblasts (HDF) are mesenchymal cells isolated from the dermis layer of the skin. HDF has the potential to be used for the treatment of wound healing based on regenerative medicine. Elevated glucose concentrations may harm function and inhibit wound healing therapy. This study was conducted to examine the effect of high glucose on proliferation, migration of HDF cell and OCT-4 gene expression as a model of diabetic wound healing in vitro. In this experimental study, fibroblasts were isolated from foreskin then grown in medium Dulbecco's Minimal Essential Medium 
(DMEM) complete with $10 \%$ serum. To test the effect of high glucose on HDF cell proliferation, the CCK-8 kit was performed. HDF cell migration was evaluated using the scratch assay test. RT-PCR is used to determine OCT-4 gene expression. The results show that high glucose (25 mM-50 mM) increases the ability of HDF cell proliferation and migration. The effect of high glucose is dosedependent, glucose treatment at a dose of $75 \mathrm{mM}$ will inhibit the growth of HDF. The expression of OCT-4 genes was significantly increased at 25-50 mM doses of glucose. The results of this study provide the basis for the development of therapy in diabetic conditions that HDF cell therapy can improve wound healing even in high glucose conditions.

Keywords: human dermal fibroblast; high glucose; proliferation; migration; OCT gene expression

\section{Pendahuluan}

Diabetes mellitus (DM) merupakan salah satu masalah utama dalam sistem kesehatan dan ancaman kesehatan masyarakat global yang telah meningkat secara dramatis selama 2 dekade terakhir. Menurut studi epidemiologi. jumlah pasien dengan DM meningkat dari sekitar 30 juta kasus pada tahun 1985, 177 juta pada tahun 2000, 285 juta pada 2010 dan diperkirakan terus meningkat. lebih dari 360 juta orang pada tahun 2030 (Yazdanpanah et al., 2015).

Kadar glukosa darah yang tinggi secara berkepanjangan akan menimbulkan penyulit pada berbagai organ tubuh seperti stroke akibat kerusakan pembuluh darah otak. kebutaan akibat kerusakan pembuluh darah mata. penyakit jantung koroner akibat kerusakan pembuluh darah koroner, penyakit ginjal kronik akibat kerusakan pembuluh darah ginjal dan ulkus diabetik akibat kerusakan pembuluh darah kaki (Waspadji. 2002). Komplikasi diabetes yaitu ulkus diabetik menyebabkan 1 juta amputasi per tahun sehingga pada tahun 2011 diperkirakan terjadi amputasi akibat ulkus diabetik setiap 20 detik di seluruh dunia. Diabetes juga menyebabkan peningkatan angka kesakitan oleh tuberkulosis dan tingginya risiko kegagalan pengobatan bahkan kematian dibanding orang yang tidak memiliki diabetes (IDF, 2011).

Ulkus diabetes merupakan salah satu komplikasi penyakit diabetes yang menjadi salah satu masalah yang sering timbul pada penderita diabetes. Ulkus diabetes menjadi masalah di bidang sosial dan ekonomi yang mempengaruhi kualitas hidup penderitanya. Masalah pada kaki diabetik misalnya ulserasi, infeksi, dan gangren, merupakan penyebab umum perawatan di rumah sakit bagi para penderita diabetes. Perawatan rutin ulkus, pengobatan infeksi, amputasi dan perawatan di rumah sakit membutuhkan biaya yang sangat besar tiap tahun dan menjadi beban yang sangat besar dalam sistem pemeliharaan kesehatan. Pengeluaran yang dihabiskan untuk diabetes mencapai $11 \%$ dari keseluruhan anggaran kesehatan. Rerata individu dengan diabetes mengeluarkan USD 1274 pada 2011 tidak termasuk biaya tidak langsung akibat hilangnya produktivitas dan perawatan (IDF. 2011).

Penanganan ulkus diabetes terdiri dari penentuan dan perbaikan penyakit dasar penyebab ulkus, perawatan luka yang baik, dan pencegahan kekambuhan ulkus. Penyebab ulkus diabetes dapat ditentukan secara tepat melalui anamnesis dan pemeriksaan fisik yang 
cermat. Ulkus diabetes mempunyai kecenderungan terjadi pada beberapa daerah yang menjadi tumpuan beban terbesar, seperti tumit, area kaput metatarsal di telapak, ujung jari yang menonjol terutama pada jari pertama dan kedua.

Kadar glukosa yang tinggi (hiperglikemi) pada penderita ulkus diabetik akan memperlambat proses penyembuhan luka. Kondisi ini juga menyebabkan kegagalan pengobatan yang dapat berakibat pada amputasi. Upaya penyembuhan dengan terobosan terkini menggunakan stem cell terus dilakukan. Untuk itu perlu lebih memahami mekanisme yang terkait dengan kondisi hiperglikemi pada saat terapi, termasuk apabila dilakukan dengan pemberian stem cell. Apakah dalam kondisi hiperglikemi stem cell masih memiliki potensi diferensiasi dan terjaga stemnessnya? Oleh karena itu dilakukan penelitian untuk mengkaji pengaruh glukosa tinggi pada proliferasi, migrasi dan ekspresi gen OCT-4 sel human dermal fibroblast sebagai model penyembuhan luka diabetes in vitro

\section{Bahan dan Metoda Penelitian}

Penelitian ini dilakukan dengan metode eksperimental secara in vitro. Sampel yang digunakan adalah sel Human Dermal Fibroblast (HDF) yang berasal dari biorepository Universitas YARSI. Kultur sel HDF ditanam dalam medium Dulbeco's Minimal Essensial Medium (DMEM) dengan Fetal Bovine Serum (FBS) $10 \%$ dan antibiotik-antimikotik ditanam dalam cawan kultur 96 sumuran dan 24 sumuran tergantung keperluan ujinya. Selanjutnya diinkubasi dalam inkubator $\mathrm{CO}_{2} 5 \%$, $37{ }^{\circ} \mathrm{C}$ sebanyak $10.000 \mathrm{sel} / \mathrm{cm}^{2}$. Masing-masing dibagi dalam 6 kelompok perlakuan dengan ulangan triplicate yaitu: Kelompok 1. Kontrol
DMEM-Non Serum (NS), Kelompok 2. Kontrol DMEM-Low Glucose (LG), Kelompok 3. DMEMHigh Glucose dosis 25 mM (HG25), Kelompok 4. DMEM-High Glucose dosis $30 \mathrm{mM}$ (HG30), Kelompok 5. DMEM- High Glucose dosis $50 \mathrm{mM}$ (HG50), Kelompok 6. DMEM-High Glucose dosis $75 \mathrm{mM}$ (HG75).

\section{Uji Proliferasi Sel dengan CCK-8}

Setelah 24 jam inkubasi dilanjutkan dengan pengukuran parameter penelitian. Untuk membaca kemampuan proliferasi sel setelah pemberian CCK-8 (Sigma). Setelah 24 jam perlakuan, medium dibuang dan dicuci dengan PBS sebanyak 2 kali. Selanjutnya ditambahkan 90 ul PBS dan 10 ul CCK-8, diinkubasi selama 90 menit. Selanjutnya sel dalam cawan kultur 96 sumuran diperiksa menggunakan microplate reader untuk dibaca optical density (OD) pada panjang gelombang $450 \mathrm{~nm}$.

\section{Uji Migrasi}

Sel HDF ditanam dalam multi well plate 24 well, masing-masing well berisi 20.000 sel/well. Setelah konfluen dilakukan scratch dengan ujung tip 100 ul. Kemudian dibilas dengan menggunakan PBS lalu diberi perlakuan dengan variasi konsentrasi kadar glukosa dan diinkubasi selama 24 jam. Setelah itu diukur pertumbuhan sel yang mengisi area bekas scratch. Untuk mengetahui kemampuan migrasi dilakukan scratch assay dan dihitung luas area pengisian sel dari setiap kelompok perlakuan.

\section{Uji ekspresi gen OCT-4}

Sebanyak 1 juta sel HDF tiap kelompok perlakuan dengan berbagai kadar glukosa dilakukan isolasi RNA total menggunakan RNA Isolation kit (Qiagen). Total RNA dihitung dengan menggunakan Qubit Fluorometer (Invitrogen). Real Time Polimerase Chain Reaction (RT-PCR) dilakukan dengan 
menggunakan Lightcycler RNA Master SYBR Green I. Primer forward dan reverse untuk OCT4 adalah 5'-AGGTGTTCAGCC AAACGACC-3' dan 5'-TGATCGTTTGCCC TTCTGGC-3'. Beta-Actin tadi digunakan sebagai house keeping gene dengan berikut urutan primer: forward 5'-AGAGCTACGA GCTGCCTGAC-3' dan reverse 5'-AGCAC TGTGTTGGCGTACAG3'.

Profil ekspresi untuk transkripsi mRNA ditampilkan sebagai cycle threshold (Ct) relative terhadap Beta-Actin.

\section{Analisis Data}

Semua data yang diperoleh kemudian dideskripsikan dengan mean $\pm \mathrm{SD}$. Analisis perbedaan dengan Anova dilanjutkan dengan post hoc uji LSD pada tingkat kemaknaan < 0,05 menggunakan SPSS.

\section{Hasil Penelitian}

\section{Kemampuan Proliferasi}

Uji proliferasi human dermal fibroblast pada berbagai perlakuan akibat pemberian glukosa tinggi menunjukkan adanya peningkatan proliferasi. Dosis glukosa $50 \mathrm{mM}$ merupakan dosis maksimal dapat meningkatkan proliferasi, selanjutnya peningkatan dosis akan menurunkan.

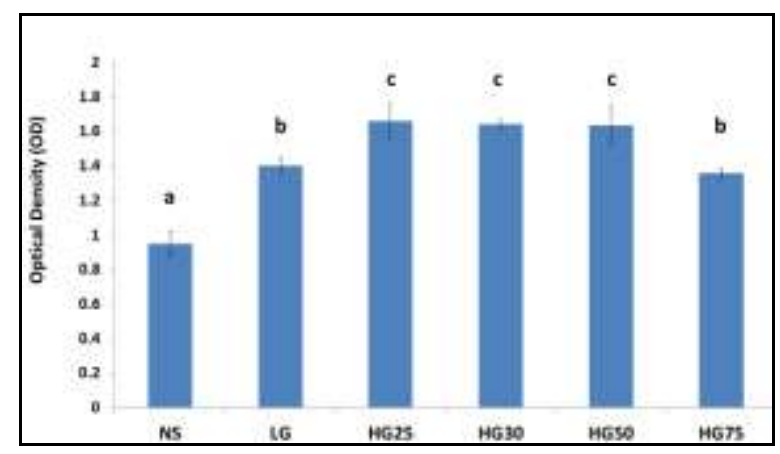

Gambar 1. Pengaruh glukosa tinggi terhadap kemampuan Proliferasi HDF. Nilai OD pada panjang gelombag $450 \mathrm{~nm}$.
Pada gambar 1 memperlihatkan bahwa pemberian glukosa diperlukan untuk proliferasi sel sampai pada batas tertentu. Kelompok kontrol tanpa serum (NS) menunjukan proliferasi paling rendah. Ini memperlihatkan bahwa serum juga diperlukan untuk proliferasi sel. Kadar glukosa rendah $(5 \mathrm{mM})$ sudah cukup untuk meningkatkan proliferasi dibandingkan kelompok tanpa serum. Demikian juga kadar glukosa tertinggi masih dapat meningkatkan proliferasi dibandingkan dengan kelompok tanpa serum.

\section{Migrasi sel}

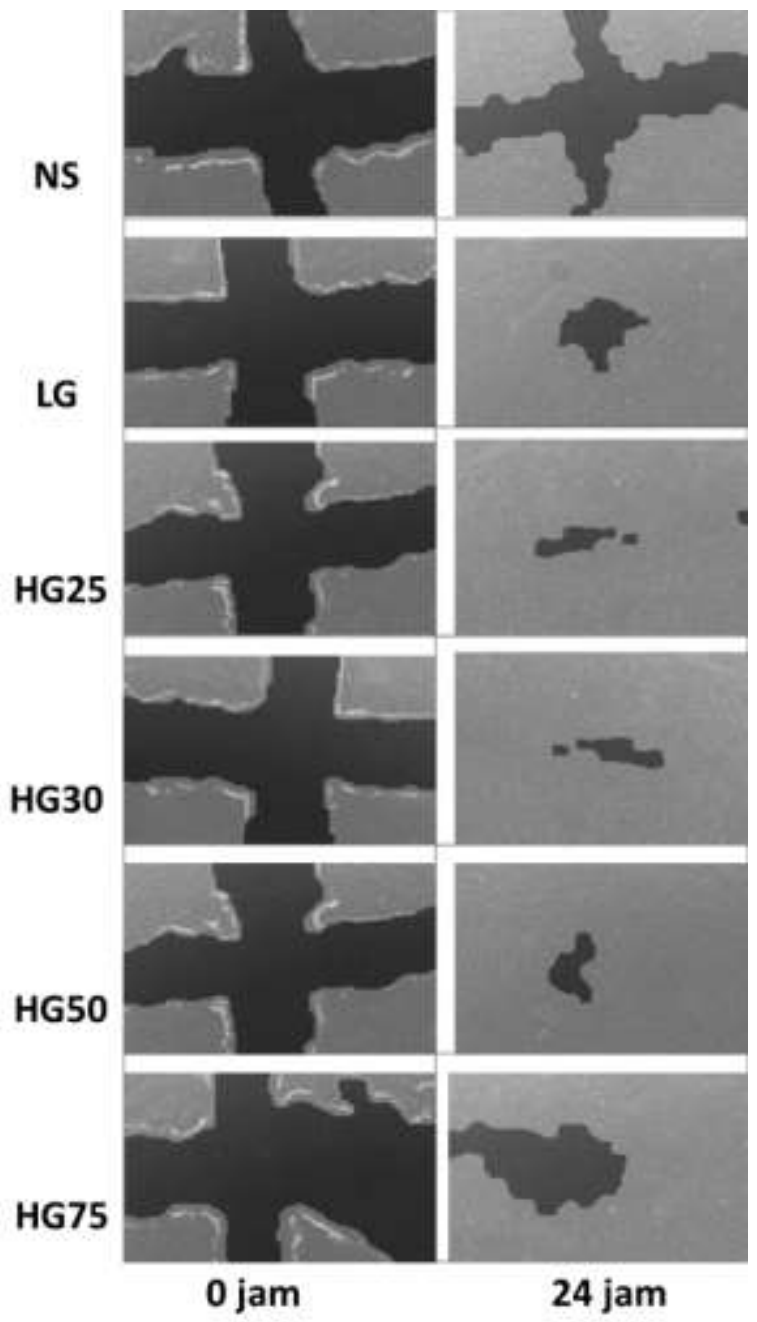

Gambar 2. Gambaran hasil uji scratch assay pada berbagai kelompok perlakuan.

Uji migrasi dimaksudkan untuk menilai kemampuan sel untuk menutup model luka yang 
dilakukan dengan menorehkan ujung tip. Semakin kecil ruang warna hitam menunjukan kecepatan migrasi sel pada penutupan model luka. Gambar 2 memperlihatkan kelompok perlakuan dosis glukosa 25 dan $30 \mathrm{mM}$ paling cepat menutup area.

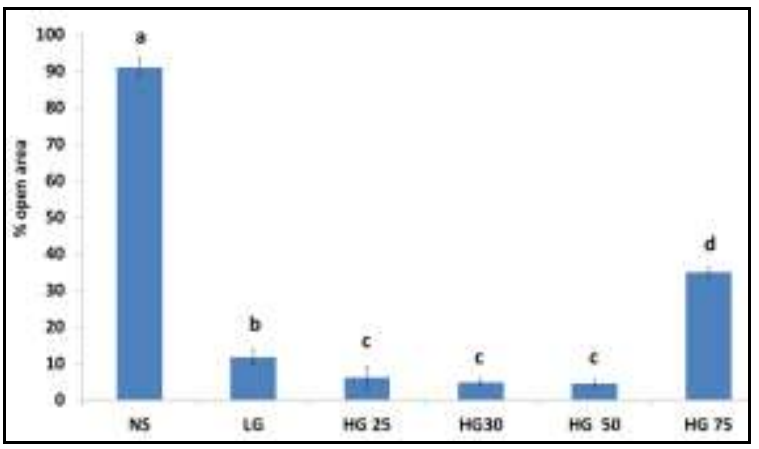

Gambar 3. Pengaruh HG terhadap migrasi sel HDF setelah 24 jam inkubasi. Open area (\%) semakin kecil menunjukan migrasi semakin cepat. Huruf beda menunjukan beda nyata $\mathrm{P}<0,05$

Uji migrasi sel HDF akibat pemberian glukosa tinggi (gambar 3) menunjukan bahwa kadar glukosa maksimal yang dapat meningkatkan migrasi sel yaitu $50 \mathrm{mM}$ dan kadar optimal $30 \mathrm{mM}$. Peningkatan kadar glukosa hingga $75 \mathrm{mM}$ menghambat migrasi sel. Hambatan migrasi paling besar diperlihatkan pada kelompok NS. Hal ini menunjukan bahwa serum diperlukan dalam proses migrasi sel. Demikian juga glukosa diperlukan untuk migrasi dengan dosis yang optimum.

\section{Ekspresi gen OCT-4}

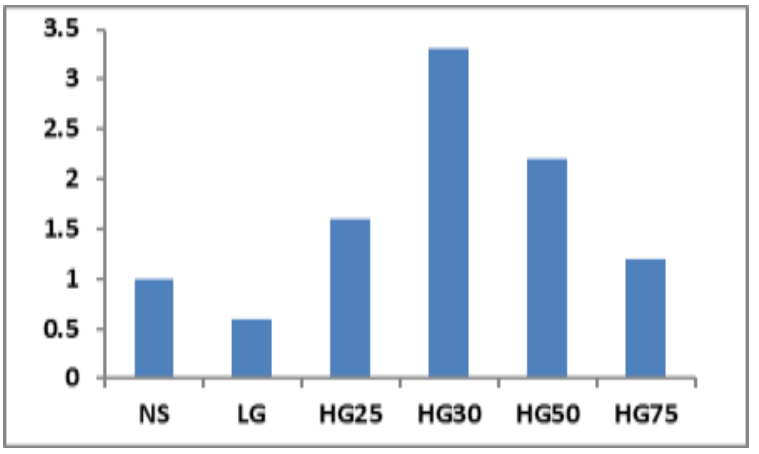

Gambar 4. Pengaruh HG terhadap Ekspresi Gen OCT-4 pada sel HDF, nilai Ct relatif terhadap kontrol NS.
Hasil penelitian ini menunjukan bahwa bahwa human dermal fibroblas hasil isolasi sel primer memiliki ekspresi basal mRNA untuk gen OCT-4. Peningkatan ekspresi gen OCT-4 secara optimal pada kelompok dengan pemberian glukosa dosis $30 \mathrm{mM}$. Peningkatan dosis glukosa selanjutnya sebaliknya akan menghambat ekspresi gen OCT-4.

\section{Diskusi}

Fibroblast dermal manusia (HFD) berperan dalam penyembuhan luka dengan cara berproliferasi ke dalam luka, sintesis komponen matriks ekstraseluler (ECM) dan remodeling bekas luka. Akumulasi dari ECM oleh fibroblas selama proses penyembuhan luka dapat disimpulkan sebagai keseimbangan antara akumulasi matriks dan degradasi. HDF mensintesis komponen ECM yaitu fibronektin dan asam hialuronat. Sintesis proteoglikan serta kolagen tipe I dan tipe III disimpan dan menjadi komponen utama dari ECM. Fibroblas juga mensintesis enzim proteolitik dan matriks metaloproteinase (MMPs yang mampu menurunkan semua komponen ECM (Zhang et al., 2016).

Peran utama dari fibroblast dalam penyembuhan luka adalah untuk menggantikan fibrin matriks sementara selama fase inflamasi dengan jaringan granulasi yang kaya kolagen. Perilaku fibroblas pada luka sangat dinamis dan bervariasi pada setiap fase penyembuhan. Fibroblas mencapai luka selama hari kedua atau ketiga setelah cedera. Empat hari setelah cedera, fibroblast menjadi jenis sel utama dalam pembentukan jaringan granulasi. Jumlah fibroblast meningkat melalui migrasi dan proliferasi sel (Golberg et al., 2013).

Penyembuhan luka dimulai dengan pembentukan bekuan darah oleh trombosit. 
pengeluaran mediator inflamasi. dan inflitrasi neutrofil dan makrofag. Pada saat yang sama re-epitelisasi dimulai untuk menutup luka dan terakhir migrasi fibroblast (Metcalfe \& Ferguson, 2007). Fibroblas dermal memainkan peran penting selama penyembuhan luka kulit. Pada tahap awal penyembuhan luka, proliferasi dan migrasi fibroblas dermal diaktifkan, yang penting untuk kontraksi luka, deposisi matriks ekstraseluler, dan pembentukan kembali jaringan. Selain itu, perbaikan luka merupakan proses kompleks yang bergantung pada interaksi antara sel efektor dan sitokin, termasuk EGF, PDGF-AA, VEGF, dan bFGF (Zhao et al., 2013).

Kadar glukosa tinggi antara $25 \mathrm{mM}$ sampai $50 \mathrm{mM}$ telah dilaporkan dapat menurunkan sintesis kolagen. Pada fibrolast asal gusi (Human Gingival Fibroblats) tanpa mempengaruhi viabilitas sel atau sintesis protein. Demikian pula telah dilaporkan bahwa glukosa tingkat 30 dan $35 \mathrm{mM}$ menyebabkan peningkatan yang signifikan dalam apoptosis pada sel endotel (Baumgartner-Parzer, 1995).

Studi lain menyiratkan bahwa dibandingkan dengan sel yang lain, jenis sel fibroblas lebih tahan terhadap kadar glukosa tinggi. Sebuah studi terbaru melaporkan gangguan migrasi sel pada fibroblas gingiva tikus setelah paparan glukosa $75 \mathrm{mM}$ selama 72 jam dan menunjukan konsentrasi glukosa yang optimal untuk kultur in vitro dari fibroblas gingiva lebih tinggi dari konsentrasi optimal in vivo (Willershausen-Zonnchen, 1991).

Studi terbaru mengungkapkan bahwa kadar metaloprotease yang tinggi merupakan ciri penderita luka diabetes dan kadar MMP dalam cairan luka kronis hampir 60 kali lipat lebih tinggi dari luka akut. Peningkatan aktivitas protease ini mendukung kerusakan jaringan dan menghambat proses perbaikan normal. Salah satu kemungkinan alasan di balik ini adalah konsentrasi glukosa yang tinggi secara langsung merubah kadar dan ekspresi MMP melalui efek pro-inflamasi dan sitokin pro-fibrotik akibat peningkatan aktivasi dan invasi inflamasi sel (Patel et al., 2019).

OCT-4 telah terbukti perlu untuk mempertahankan pluripotensi sel punca embrionik. OCT-4 dianggap sebagai pengatur utama dari pluripotensi. Selain gen OCT-4 yang diaktifkan adalah gen Sox2 dan Nanog. Seiring dengan OCT-4, gen ini juga diperlukan untuk mempertahankan sel dalam keadaan kemampuan pluripoten (Racila et al., 2011). Pada penelitian ini kadar glukosa tinggi dengan dosis $25-50 \mathrm{mM}$ masih dapat mempertahankan pluripotensi dengan meningkatkan ekspresi gen OCT-4, selanjutnya akan menurun dengan peningkatan kadar glukosa tinggi $75 \mathrm{mM}$.

Dengan demikian meskipun pada model hiperglikemia pengaruh kadar glukosa tinggi masih dapat mempertahankan kemampuan proliferasi, migrasi dan pluripotensi namun semakin tinggi kadar glukosa akan sebaliknya. Hal ini sesuai dengan penelitian sebelumnya yang menunjukkan kadar tinggi glukosa menyebabkan gangguan pada proses penyembuhan luka diabetik. Hanya saja penggunaan model dengan sel fibroblast manusia pada penelitian ini menunjukkan bahwa sel fibroblast (HDF) lebih toleran terhadap kadar glukosa tinggi.

\section{Simpulan}

Kemampuan proliferasi, migrasi dan ekspresi gen OCT-4 masih dapat dipertahankan dalam keadaan glukosa tinggi tergantung dosis. Pemberian kadar glukosa tinggi memberikan dasar untuk pengembangan terapi dalam 
kondisi diabetes bahwa terapi sel dermal fibroblast manusia dapat meningkatkan penyembuhan luka meskipun dalam kondisi glukosa tinggi.

\section{Daftar Pustaka}

Baumgartner-Parzer SM, Wagner L, Pettermann M, Grillari J, Gessl A, WaldhausI W. 1995. High-glucose-D triggered apoptosis in cultured endothelial cells. Diabetes. 44(11):1323-7.

Golberg A. et al., 2013. Regeneration and control of human fibroblast cell density by intermittently delivered pulsed electric fields. Biotechnology and Bioengineering. 110(6). pp.1759-1768.

International Diabetes Federation (IDF). 2011. Panduan Global untuk Diabetes Tipe 2 http://communication@idf.org NIH. (2006). Regenerative Medicine. Department of Health and Human Sevices USA.

Metcalfe and Ferguson. 2007. Tissue engineering of replacement skin: the crossroads of biomaterials, wound healing, embryonic development, stem cells and regeneration, $J R$ Soc Interface. Jun 22; 4(14): 413-437.

Patel S, Shikha Srivastava, Manju Rawat Singh, Deependra Singh. 2019. Mechanistic insight into diabetic wounds: Pathogenesis, molecular targets and treatment strategies to pace wound healing, Biomedicine \& Pharmacotherapy $112: 108615$.
Racila D, Michael Winter, Mohammed Said, Ann Tomanek-Chalkley, Susan Wiechert, Richard L. Eckert and Jackie R. Bickenbach. 2011. Transient expression of OCT-4 is sufficient to allow human keratinocytes to change their differentiation pathway, Gene Ther. Mar; 18(3): 294-303.

Waspadji S. dkk. 2002. Pedoman Diet Diabetes Mellitus Jakarta: Balai Penerbit Fakultas Kedokteran Universitas Indonesia. Halaman 7-8

Willershausen-Zonnchen B, Lemmen C, Hamm G. 1991. Influence of high glucos concentrations on glycosaminoglycan and collagen synthesis in cultured human gingival fibroblasts. J Clin Periodontol; 18(3):190-5.

Yazdanpanah L. Nasiri M and Sara Adarvishi. 2015. Literature review on the management of diabetic foot ulcer. World J Diabetes. Feb 15; 6(1): 37-53.

Zhang W. Yun Zhu, Jia Li. et al., 2016. CellDerived Extracellular Matrix: Basic Characteristics and Current Applications in Orthopedic Tissue Engineering Tissue engineering: Part B Volume 22.3.

Zhao J, Li Hu, Jiarong Liu, Niya Gong and Lili Chen. 2013. The Effects of Cytokines in Adipose Stem Cell-Conditioned Medium on the Migration and Proliferation of Skin Fibroblasts In Vitro, Biomed Res Int: 578479. 